\title{
Aquinas on Aristotle on Happiness
}

\author{
Don Adams
}

The first nine books of Aristotle's Nicomachean Ethics (EN) seem to present a complex theory of happiness. In them, it seems that happiness is a good that is composed of several goods, e.g., friends, wealth, political and social honors, and so on. There seems now to be a consensus that this is indeed Aristotle's considered view of happiness. ${ }^{1}$ I agree with this consensus.

Given that the first nine books of the EN seem so clearly to suggest this active view of happiness, it seems odd that in his commentary on

I. See the following: J. Cooper, Reason and Human Good in Aristotle (Cambridge, Mass.: Harvard University Press, 1975), p. 99; D. Keyt, "Intellectualism in Aristotle," Paideia, Special Aristotle Issue (1978): 138-157; J. Whiting, "Human Nature and Intellectualism in Aristotle," Archiv für Geschichte der Philosophie 68 (1986): 7095; J. L. Ackrill, "Aristotle on Eudaimonia," in Essays on Aristotle's Ethics, edited by A. Rorty (Berkeley: University of California Press, 1980), pp. 15-33; T. H. Irwin, Aristotle, Nicomachean Ethics (Indianapolis: Hackett, 1985); Irwin, "Permanent Happiness: Aristotle and Solon," in Oxford Studies in Ancient Philosophy 3, edited by J. Annas (Oxford: Oxford University Press, 1985), pp. 89-124; Irwin, "Stoic and Aristotelian Conceptions of Happiness," in The Norms of Nature, edited by M. Schofield and G. Striker (Cambridge: Cambridge University Press, 1986), pp. 205244; A. W. Price, "Aristotle's Ethical Holism," Mind 89 (1980): 341; M. Nussbaum, "Aristotle," in Ancient Writers 1, edited by T. James Luce (New York: Scribner, 1982), p. 403; D. Devereux, "Aristotle on the Essence of Happiness," in Studies in 
the $\mathrm{EN},{ }^{2}$ St. Thomas Aquinas attributes to Aristotle a view quite similar to his own contemplative view of happiness. In this essay I intend to show that while Aquinas's interpretation of Aristotle ${ }^{3}$ is incorrect, it is philosophically interesting, textually well motivated, and guilty of no interpretative crimes.

I begin by pointing out two early symptoms of the difference between Aristotle's views and the views that Aquinas attributes to Aristotle. Next, I clarify the character of the two different conceptions of happiness and raise a serious problem for Aquinas's attempt to attribute to Aristotle a view of happiness so similar to his own. Finally, I show the textual root of the difference between Aristotle's views and Aquinas's interpretation of Aristotle's views and show that given the text Aquinas had, and given the burden of interpreting Aristotle sympathetically, Aquinas's interpretation is guilty of no interpretative crimes.

\section{TWO SYMPTOMS OF DIFFERENCE}

Aquinas follows Aristotle in arguing that happiness is a complete (teleia, perfectus) and self-sufficient (autarkes, per se sufficiens) good (EN 1.7.1097a25-b15, EA 1.9 no.107). ${ }^{4}$

\section{COMPLETENESS}

At the end of EN 1.10 Aristotle admits that the happiness which can be attained in this life is subject to chance. Even

Aristotle, edited by D. J. O'Meara (Washington: The Catholic University of America Press, 1981), p. 249f. Two recent dissenters from this consensus are Robert Heinaman, "Eudaimonia and Self-Sufficiency in the Nicomachean Ethics," Phronesis 33 (1987): 31-53; and Richard Kraut, Aristotle on the Human Good (Princeton: Princeton University Press, 1989). Heinaman's reasons for dissenting bear little relation to Aquinas's interpretation of Aristotle, so I shall not respond to Heinaman here. I shall, however, respond briefly to Kraut in note 31 , below.

2. I shall use "EA" to refer to Aquinas's commentary on the Ethics of Aristotle. For ease of citation, I will use both the medieval textual divisions and the section numbers originally assigned by Cathala, as reproduced in In decem libros Ethicorum Aristotelis ad Nicomachum expositio, 3d ed., edited by Raymundus M. Spiazzi (Turin: Marietti, 1964). All translations of Aristotle and Aquinas are mine.

3. I do not intend to look carefully at the first five questions of Summa theologiae (hereafter ST) 1-2, which could also be considered to be a type of commentary on EN.

4. Aquinas takes b16-20 to be a further explanation of self-sufficiency and not to 
someone as prosperous as Priam can be denied happiness because of serious misfortune. (Although misfortune cannot make one unhappy, it can deprive one of some external goods required for complete happiness. $)^{5}$ This does not commit Aristotle to the view that happiness is a radically unstable or ephemeral thing, since it takes serious misfortune to take one's happiness away. Aquinas does recognize that Aristotle does not think "a person is happy in the way of a chameleon" (1.15 no. 186) and sees that this does not by itself entail that happiness is radically unstable. Nevertheless Aquinas does think that Aristotle accepts that once we admit that the happiness to be obtained in this life can be taken away by misfortune, we must accept that it cannot be truly complete. Aquinas says, "but because these things do not seem always to measure up to the conditions for happiness laid down above," i.e., completeness and self-sufficiency, as in EA 1.9 nos. 104117, "he adds that the sort of people we call happy as human beings, who in this life are subject to change, cannot have complete happiness" (EA 1.16 no. 202). It is the mutability of this life that, according to Aquinas, rules out even the possibility of its being complete in the relevant sense. (Aquinas takes two different lines in different places about what the relevant sort of mutability is. I will return to this point below.)

This is an odd comment for Aquinas to make for two reasons: first, nowhere in the passage he is commenting upon does Aristotle explicitly deny human beings the ability to attain complete happiness in this life; but, second, the point of Aristotle's argument seems to be exactly the opposite. ${ }^{6}$ Aristotle asks rhetorically:

What, therefore, prevents us from calling happy the one who acts according to complete virtue and is thoroughly and sufficiently supplied with external goods not for a short time but in a complete life? . . . we lay it down that happiness is the end and is always complete in every way. But if

be a third feature of happiness. Taking it this way is at least strongly recommended by b20-21.

5. For one explanation of how this can be so, see Irwin, "Permanent Happiness," pp. $89-124$.

6. If in book 10 Aristotle clearly claims that the active life can never be as complete as the contemplative life, there would be good reason to try to interpret this passage in the way Aquinas does. I shall return below to Aristotle's discussion of the contemplative life in book 10 . 
it is so, we will call blessed a living human being to whom belongs and will belong the things we have said, but happy as a human being. ?

The point here seems clearly to be that while complete happiness is difficult to attain in this life, it is possible-however difficult it might be to attain complete virtue and sufficient external goods or to avoid misfortunes.

In defending his interpretation, Aquinas may point out that Aristotle does say that when one is happy in the way he is discussing, one is happy "as a human being." Surely in saying this he is acknowledging at least that there may be another way of being happy (compare EA 1.16 no. $202 ; 1.9$ no. 113). But to justify his interpretation, Aquinas must show that according to Aristotle (1) there is another way of being happy which (2) has a better claim on being called complete and which (3) we can, at least theoretically, achieve. ${ }^{8}$ Aristotle accepts claim 1 since he believes that the happiness of the gods is different from human happiness (compare EN 7.14.1154b26-31; and Metaphysics 12.7.1072b14-20). We will see that Aquinas also attributes claims 2 and 3 to Aristotle.

\section{SELF-SUFFICIENCY}

Aquinas follows Aristotle in holding that a good is selfsufficient if and only if it provides everything that is by itself necessary and sufficient for making a life "choiceworthy, lacking in nothing"

7. In this section (EN 1.10.1100b33-1101a21), Aristotle seems to be using "happy" (eudaimôn) and "blessed" (makarios) interchangeably (compare especially 1100b33-34 with 1101a6-8). Aquinas appears to follow him, using felix and beatus interchangeably (see especially EA 1.15 no. 185). Compare also 1099b9-18 and 1098a19. In his comment on this last passage (EA 1.10 no. 129) Aquinas explicitly mentions that "in praesenti vita non potest esse perfecta felicitas" but nowhere uses beatus or any of its cognates, which he should do if it were important for him to distinguish the beatus from the felix.

8. By condition 3, I mean two things: (3a) it is logically possible for some person to be happy in that other way, and $(3 \mathrm{~b})$ it is logically possible for such a person to be numerically identical to someone who is a human being. Perhaps conditions 1 and 2 by themselves could help show that some nonhuman person is not completely happy, but without conditions $3 \mathrm{a}$ and $3 \mathrm{~b}$, they cannot show that the happiness of some human being is not complete. Even if neither Aquinas nor Aristotle assumes that complete happiness is logically possible, conditions 1 and 2 without $3 \mathrm{a}$ and $3 \mathrm{~b}$ will not count as evidence that a human being leading the active life on earth is not completely happy. 
(EA 1.9 no. 114; compare EN 1.7.1097b14-15). This is ambiguous, depending upon how we construe the subsequent few lines. I follow Irwin ${ }^{9}$ in thinking that Aristotle takes it in the following way:

[Happiness] is the most choiceworthy of all, not being merely one good among many - if it were merely one good among many, then clearly it would be made more choiceworthy by the addition of the least of goods, [but since it is the most choiceworthy, the addition of the least of goods will not make it more choiceworthy, so happiness is not merely one good among many].

This is the inclusive sense of self-sufficiency: if $G_{1}$ by itself makes a life choiceworthy, but a life with $G_{1}$ is made more choiceworthy by the addition of $G_{2}$, then $G_{3}$ (let $G_{3}=G_{1}+G_{2}$ ) is more self-sufficient than either $G_{1}$ or $G_{2} \cdot{ }^{10}$

According to Aquinas, there are two different ways in which something can be said to be self-sufficient. The first way is the inclusive way just mentioned. "In one way, a complete [perfectum] good is said to be self-sufficient if it cannot receive an augmentation of good through the addition of any good thing" (EA 1.9 no. 115). In this sense, the self-sufficient good $G$ is the one that already includes all token goods which, if added to $G$, would augment the goodness of G. Aquinas thinks that the only being in the universe that is selfsufficient in this way is God (EA 1.9 no. 115).

The second way in which a good can be said to be self-sufficient, according to Aquinas, is exclusive.

By itself, nothing else included, [a self-sufficient good] is sufficient insofar as it contains everything that a human being needs of necessity . . . nevertheless, if it is included together with anything else even minimally good, clearly it will be more choiceworthy. This is because through addition there is a superabundance or augmentation of good. So the more good a thing is, the more choiceworthy it is. (EA 1.9 nos. 115-116)

This is an exclusive sense of self-sufficiency. Suppose $G_{1}$ is a selfsufficient good and suppose that the addition of $G_{2}$ makes $G_{1}$ more

9. Irwin, "Permanent Happiness," p. 93.

I0. What Aristotle says at 10.2.1172b28-34 appears to, but need not really, support the inclusive interpretation. In this passage Aristotle may be saying only that the good cannot be made better by the addition of a new type of good thing. This does not commit him to the view that the good cannot be made better by the addition of a new token good thing, the view to which I take the inclusive interpretation to commit him. 
choiceworthy. We now have two self-sufficient goods, $G_{1}$ and $G_{3}$ (where $G_{3}=G_{1}+G_{2}$ ). Both $G_{1}$ and $G_{3}$, therefore, provide all the "necessities of life," but $G_{1}$ is more self-sufficient than $G_{3}$, according to Aquinas, because it does not require $\mathrm{G}_{2} \cdot \mathrm{G}_{3}$ depends upon having $G_{2}$ in addition to $G_{1}$, whereas $G_{1}$ is not dependent on the extra $G_{2}$.

The idea here, presumably, is something like this. Select a person, $S$, whom Aristotle would be willing to call happy. $S$ has everything necessary for happiness, so S's life is self-sufficient and choiceworthy. Suppose now that in fact $S$ has one million dollars, which $S$ uses for admirable public works, benefitting friends, and so on. It seems clear that it would be an additional good for $S$ to possess an additional million dollars, for $\mathrm{S}$ could then sponsor more or greater public works, more greatly benefit more friends, and so on. However, by hypothesis, this additional million is not necessary for $S$ to be happy. So S's life with the extra million is better, and hence more choiceworthy, than S's life without the extra million. But since we said that S's life without the extra million was a happy life, it turns out that some state is more choiceworthy than the state of being happy.

Given such a story, the inclusive view seems wildly implausible. On the inclusive view we must either accept that the additional million does augment the goodness of S's life, but deny that $S$ was happy without the additional million; or accept that $S$ was happy without the extra million, and deny that the extra million augments the goodness of S's life. Both options seem implausible. I would like next to try to make the inclusive view seem less implausible.

\section{THE INCLUSIVE VIEW}

A clean and well-made pair of shoes is a good thing. In modern city life, one needs several such good things in order to lead a happy life. If I had no shoes, it would make my life better were a decent pair of shoes to be added to my life. A second decent pair of shoes also might make my life better. From this, however, it does not follow that it is always the case that another decent pair of shoes will make my life that much better. It is not always true that if $n$ good things improve one's life by $n$ degrees, then $n+1$ good things improve one's life by $n+1$ degrees. There comes a point, at least with respect to shoes, when enough is enough. This must be true because there is such a thing as having too many shoes. There is a number of pairs of 
shoes $n$ such that having $n$ pairs of shoes actually makes one's life a bit worse than if one were to have significantly fewer than $n$ shoes. But here I must make an important exception.

If I had nothing at least as important to do as clean and organize my shoe collection, then perhaps I would always count an extra pair of shoes as an improvement of my life. However, if I do happen to have other things to do which are at least as important as maintaining my shoe collection, then there comes a point where maintaining that collection takes time away from other worthwhile projects, making my life worse. Or, if I fail to maintain the collection, the clutter makes it difficult to get anything done in my apartment, thus making my life worse. It is possible to have too much of a good thing. Well and good for shoes, but how about for a million dollars?

Perhaps it never hurts to have a little more money. However, the fact that $x$ never hurts does not entail that $x$ always helps. By hypothesis, $S$ was happy without the extra million. Now we give $S$ an extra million, and clearly we have not hurt $S$ or made S's life worse. But have we really improved S's life? Before getting the extra million, $S$ had more to do with her time than simply spend money on friends and noble public works. Where will $S$ find the time to spend the extra million? But perhaps time is not the problem. Perhaps $S$ will take exactly the same amount of time spending money, but during that time $S$ will plan larger, more expensive public works, give more to the same friends, and so on. In this case, isn't more necessarily better? Clearly not.

It is quite true that the virtuous person will work for her friends and her country, and will sacrifice her money and be willing even to sacrifice her life for them (EN 9.8.1169a20). However, she will also be willing to sacrifice actions to her friends or her country, allowing others to perform noble deeds themselves (EN 9.8.1169a33). Perhaps it never hurts a magnificent person to receive more money, but the magnificent person may never use some of the extra money. The magnificent person knows when and how much not to spend as well as when and how much to spend (EN 4.2.1123a20-27). But we need not think of such extreme circumstances.

There is a second reason why it is not true that the greater the public work is, the better the magnificent act is. A magnificent act must be "fitting," but what is "fitting" is determined relative to the giver (EN 4.2.1122a25 and b25). Surely a magnificent person gives 
readily and easily, without counting every penny (1122b7), but she also does not overreach her budget. She spends what is "fitting." But so does the magnificent person with twice as much money as $\mathrm{S}$. They are both doing what is fine and "fitting" on a grand scale-Aristotle does not tell us just how grand the scale must be in order to count as a magnificent work - and so they are both doing perfectly magnificent things. Consequently, if S has one million, and P has two million, P's public works may be on a grander scale than S's, but that does not entail that $\mathrm{P}$ is more magnificent than $\mathrm{S}$, and so it does not entail that P's life is any better than S's.

Now the inclusive view may not seem so implausible. Suppose that $S$ is happy, and that S's net worth is one million dollars. Since she is happy, she must be exercising all the virtues. She is engaging in large, noble public works, she helps out her friends and family, she takes care of her own business, goes to parties and other social gatherings, and she takes time off to relax, enjoy the company of her friends, and to study. Now we give $S$ a second million dollars. I assume we have not made her life worse. Have we really improved it? Before she was exercising her virtues to the fullest, benefitting her friends and the community in large and small ways. Afterwards she continues to exercise the virtues to the fullest, benefitting her friends and the community in large and small ways. It looks as if the change in her life is superficial and does not make it any better. Of course there is room for intuitions to differ here, but I hope this at least makes the inclusive view seem less implausible than it did at first.

If this does help the theory of happiness that Aristotle lays out in book 1 of the Ethics, we might nevertheless wonder how to square it with Aristotle's claims in book 10 about what he thinks can actually instantiate the concept of happiness. ${ }^{11}$ In book 10 Aristotle appears to accept the exclusive interpretation of self-sufficiency when it comes to describing the actual sort of life which would instantiate happiness. He seems to say that the contemplative life is preferable to the active life because it is more self-sufficient, in spite of the fact that in the

I I. We can distinguish between the concept of self-sufficiency and what in fact Aristotle thinks instantiates the concept of self-sufficiency. In fact, however, I think that Irwin is right about how to translate EN 1097b14-15, and so I think that even in book 1, Aristotle does not sit on the fence about self-sufficiency, but states the inclusive view. 
contemplative life, one must give up many choiceworthy things. ${ }^{12} \mathrm{I}$ will turn to this issue soon, but there is another to be taken up first. I have already explained what a completely happy life might look like on the inclusive view of self-sufficiency. What might it look like on an exclusive view?

\section{TYPES OF HAPPINESS}

A good is complete if and only if it is always chosen for its own sake and never for the sake of something else (EN 1.7.1097a30-34; EA 1.9 nos. 109-111). In this sense, according to Aquinas, someone who has attained her complete good has attained the "ultimate terminus of the natural motion of desire," and so she must not be merely potential in any relevant way, but must have all of her potentialities fully actualized (1.9 no. 107). While it is not obvious that Aristotle understands completeness in just this way, he does believe that a happy person must be completely actual in this sense because he believes that happiness consists in fulfilling one's nature. But here we must draw a few distinctions.

\section{ACTUALITY AND POTENTIALITY}

Consider someone who knows nothing of French or Mandarin. If she is of normal intelligence, then she has the capacity to learn both languages. Call this capacity a "first potentiality." 13 Now suppose she learns both French and Mandarin. She has exercised her first potentiality and has a developed capacity that explains why, for example, she knows what the Mandarin word for "chair" is. Call this actualized first potentiality her "first actuality." This first actuality, however, is also a potentiality, since in virtue of knowing French and Mandarin, she has the capacity to speak either language at will. So the first actuality is the "second potentiality." Finally, when she is actually

12. Specifically at EN 10.7.1177a15 and 1178a2 Aristotle appears to make such claims. Aquinas takes advantage of these passages in EA 10.10 nos. 2080-2086 and 2107-2110 to attribute the exclusive view to Aristotle. I argue below that this is a reasonable interpretation of Aristotle, provided that we can attribute to Aristotle the view that someone numerically identical to me could be completely fulfilled without living the active life.

I 3. For these distinctions, see Aristotle's On the Soul 2.1, 2.5; Metaphysics 4.3, 4.5, 4.7-8, 5.12, 5.20; and Aquinas's ST 1-2.49. 
speaking French or Mandarin, she is actualizing her second potentiality; call this the "second actuality."

Since there are two kinds of actuality, there are two ways of being perfectly actual: (1) being actualized in all of one's first potentialities but not all of one's second potentialities (call this "perfectly 1 actual"), and (2) being actualized in all of one's second potentialities (call this "perfectly 2-actual"). ${ }^{14}$ Cutting across this distinction is a threefold temporal distinction: is one perfectly actual only over a period of time, or is one perfectly actual all at once though impermanently, or is one perfectly actual at a time and permanently? In the previous example it is clear that no one can be perfectly 2 -actual at a time, permanently or impermanently. It is impossible to be speaking both French and Mandarin at the same time (for any length of time, let alone permanently). One can, however, be perfectly 2-actual over time: one can first speak French, and then Mandarin. One can be perfectly 1 -actual both at a time and over time: I can have a fully developed character with all the relevant first potentialities developed, or I might lose certain character traits while developing others, so that I have developed each first potentiality at some time, though there has never been a time when all of them were actualized simultaneously.

Since Aquinas and Aristotle accept that happiness requires perfect actualization, we must ask which of the four kinds of perfect actualization they require. It is clear that both think being perfectly 1 -actual is not enough, for one can be perfectly 1-actual and spend most of one's life asleep or in a coma, in which case one surely would not be happy (EN 1102a32-b12; EA nos. 231-235). ${ }^{15}$ So both think that happiness requires being perfectly 2 -actual. Which type of being perfectly 2 -actual does Aquinas think happiness requires?

We saw earlier that Aquinas attributes to Aristotle the belief that mutability rules out even the possibility of a life's being complete. In different places Aquinas understands this mutability differently. In his

14. This definition of "perfectly 2 -actual" is ambiguous. One satisfies this definition by actualizing all of one's second potentialities even if one has not actualized all of one's first potentialities. When I use "perfectly 2-actual," I will mean one who has actualized all of her or his first potentialities.

15. See also EN 1.8.1098b30-1099a7; EA 1.10 nos. 119 and 123-130, 1.12 nos. 152-153, 10.9 no. 2066. 
commentary on the EN, Aquinas is fairly clear that the relevant sort of mutability is the possibility that one will change from being happy to being not happy (EA 1.16 nos. 201-202; 1.10 129). Because human happiness requires external goods, and because it is always possible that severe misfortune will take those goods away, it is always possible (in this life) to change from being happy to being unhappy. Aquinas also mentions that continuity is necessary for happiness (EA 1.10 no. 129). Because this life will end, we cannot have perfect continuity in this life, hence we cannot have perfect happiness.

Aquinas employs different notions of mutability and continuity in the ST. At ST 1-2.3.2 ad 4, Aquinas cites EN 1.10 (the passage he expounds in EA 1.16 nos. 201-202) to support his claim that much stronger sorts of mutability and continuity rule out the possibility of our being perfectly happy in this life.

In human beings, as regards the condition of this present life, the final perfection accords with an activity by which a human is joined to God; but this activity cannot be continuous. Consequently, neither is it unique, because an activity is multiplied by being discontinued, and on account of this, in the condition of this present life, perfect happiness cannot be possessed by a human being. . . . Consequently the active life, which is occupied with many things, fits the definition of happiness less than the contemplative life which is occupied with one thing.

Here it is clear that the discontinuity is, for example, the fact that we have to leave off exercising one virtue in order to exercise another (or to sleep, for which see ST 1-2.3.2 ad 6 which Aquinas claims to have answered in ad 4). This is significantly different from the view taken in the EA. We might express this difference in the terminology introduced above by saying that in the ST, the fact that we cannot attain perfect 2 -actuality at a time permanently or impermanently (but at best only perfect 2 -actuality over time) ${ }^{16}$ by itself rules out the possibility of our being perfectly happy. ${ }^{17}$ While the EA never suggests any such criterion, it does not explicitly rule it out either. Before we go

16. I cannot exercise all of my developed capacities at the same time (perfect 2 -actuality at a time) but only over time. I cannot exercise all the virtues at once; rather, I must exercise first one, then cease exercising that one and then exercise another and so on (perfect 2-actuality over time).

I 7. This seems to be what underlies Pegis's interpretation of Aquinas's commentary on Aristotle. See Anton Pegis, "St. Thomas and the Nicomachean Ethics: Some Reflections on Summa contra gentiles III, 44, 5," Mediaeval Studies 25 (1963): 1-25. 
any further, we should examine what reason someone might have for preferring perfect 2 -actuality at some time, permanently or impermanently, over perfect 2-actuality only over time.

\section{HAPPINESS AND DESIRE}

Alan Donagan sketches one motivation for preferring perfect 2-actuality at a time and permanently over perfect 2 -actuality only over time. ${ }^{18} \mathrm{He}$ writes that "nobody who believes the Christian revelation can seriously imagine that those who see God face to face can have anything more to want . . . the only thing that will put an end to the restless striving of human beings is the vision of God" (p. 33). He then claims that we can make sense of this on the basis of something Bertrand Russell once argued. ${ }^{19}$ In one section of the passage Donagan refers to, Russell says this: "The primitive non-cognitive element in desire seems to be a push. . . . Certain sensations and other mental occurrences have a property which we call discomfort; these cause such bodily movements as are likely to lead to their cessation" (p. 38). The cessation, however, is only temporary, and so the striving for satisfaction must continue. Perfect 2 -actuality only over time does not solve this problem (if it is a problem), because one achieves perfect 2-actuality over time as a result (if Russell is right) of recurrent pain that drives one on to the next satisfaction. Perfect 2 -actuality over time does not provide a way to avoid the pain of continual desire: while I satisfy one desire, the other desires ache to be satisfied. On the contrary, if one is perfectly 2 -actual at a time, then at that time, one has none of those pushes and so (if Russell is right) none of the discomfort mentioned. This would be a clear reason to prefer the latter over the former if such continual striving is a problem that we should want to solve. To decide this we must decide which is better: continual striving, or the state that results from successfully curing the striving.

In the same place Russell describes the cured state in this way: "When the discomfort ceases, or even when it appreciably diminishes,

18. Alan Donagan, Human Ends and Human Actions: An Exploration in St. Thomas's Treatment (Milwaukee: Marquette University Press, 1985). Page references are given parenthetically in the body.

19. Donagan refers to Bertrand Russell, The Analysis of Mind (London: George Allen and Unwin, Ltd., 1921). Page references are given parenthetically in the body. 
we have sensations possessing a property which we call pleasure." If this is all there is to recommend perfect 2-actuality at some time, and Aquinas chooses it for this reason, then Aquinas turns out to be a hedonist. He would have to accept that our ultimate end is simply to be in the state of having satisfied all the desires one happens to have. But Aquinas clearly rejects this hedonism, ${ }^{20}$ so Donagan does well not to attribute this part of Russell to Aquinas.

Donagan does point out part of Aquinas's motivation: ${ }^{21}$ as long as we are still desiring things, there are still things that we take to be goods and which we lack-at least we lack them when we desire them. ${ }^{22}$ To avoid the hedonism he rejects, Aquinas must avoid making the connection Russell makes between desire-satisfaction and pleasure. On the plain desire-satisfaction view of happiness, what there is to recommend happiness to us is that it is the state in which all our desires have been brought to rest. Rest comes, not, as Schopenhauer would have it, by ceasing to have desires (without satisfying them), but by fulfilling all one's desires. On this view of happiness, perfect 2 -actuality at some time (permanently or impermanently) is to be preferred to perfect 2-actuality only over time because in the latter, one never achieves the state of having all of one's desires simultaneously at rest.

This view is open to an Aristotelian objection. We are social animals by nature, and so our happiness must consist in the laborious process of exercising our potentialities over time in community with others here in our animal bodies. Aristotle might admit that Aquinas has shown that (1) there is another type of happiness, and that (2) this other type of happiness has a better claim on being called "complete," but Aristotle would deny that we can, even theoretically, be happy in that way. Perhaps there is some being whose happiness would not be complete if it were living a life like mine, but that does not tell me that my happiness is not complete.

20. See EN 1.5.1095b14-22, 10.6.1176b9-1177a11; and EA 1.5 nos. 56-61, 10.9 nos. 2071-2079.

21. Compare ST 1-2.5.8 where Aquinas says that "to desire happiness is nothing else than to desire that one's will be satisfied." See also $1-2.4 .5$ ad 5, and 1-2.3.8, where he says that "man is not perfectly happy, so long as something remains for him to desire and seek."

22. If we achieved what we desired, then we would no longer be desiring it, we would be enjoying it; cf. ST 1-2.11.3. 


\section{THE ROOT OF THE DIFFERENCE}

Aquinas deals with this at ST $1-2.188 .8$ ad 5 by arguing that we don't have to remain sociable by nature.

A human being can live a solitary life in two different ways. First, as being unable to tolerate human society . . . and this is brutish. Secondly, because he is immersed in divine things, and this is something superhuman. Hence Aristotle says, "He who does not associate with others is either a beast or a god," that is, a godly man.

Here we begin to get to the root of the difference between Aquinas and Aristotle, for in the Aristotelian passage Aquinas quotes here, Aristotle commits himself to the view that no human being can become a god in the relevant sense. At EN 1166a20-22 he says: "No one chooses [hairetai] to have all [good things] becoming another (for as it is, the god has the good), but [one chooses good things for oneself] being what one is" (EN 9.4 1166a20-22). ${ }^{23}$ The Greek for the last phrase is "all' ôn ho ti pot' estin." The only word I have not translated is pote. There is an ambiguity in the force of this word. It can be just a throwaway word, not worth translating, ${ }^{24}$ or it can add a temporal notion to a sentence. ${ }^{25}$ Depending upon what we take to be the subject of the phrase "all' ôn ho ti pot' estin," the pot' may or may not have temporal force. As I have translated the passage above, the all' ôn phrase refers to the subject of hairetai at the beginning of the quotation, and if we take it this way, there would be no sense to a temporal force in the pot'. ${ }^{26}$

If, however, one thought that the subject of the all' ôn phrase were

23. Aristotle has at least good prima facie evidence for this view. If a human being lost the capacity of sociability, then she would lose the capacity to care about the common good for its own sake (cf. 8.1.1155a22-28), and since every virtue aims at the common good (because it aims at the fine, 5.1.1129b11-19; 3.7.1115b11-13), she would lose the capacity for having any human virtue. Such a person could not count as a human being. Because Aquinas has a different view of the common good, he need not deny concern for the common good to a person who is no longer a social animal by nature.

24. Compare EN 8.7.1159a10 where, quite reasonably, the Latin translator simply does not translate the pot'.

25. For example, "Athênaios tis erôtêsê pote ton Periclea" ("an Athenian once asked Pericles").

26. Bywater takes the passage this way and so encloses in parentheses the clause "for as it is, the god has the good" to make it clear that it is semantically and syntactically separate from the all' ôn phrase. 
"god" in the phrase "the god has the good," there might be some temporal force to the pot'. The Latin translation Aquinas uses takes the pot' this way and so translates it as aliquando, "at any time": "No one chooses to have all [good things] becoming another. (For as things are, God has the good, but he always is what he is at any time.)" While this is a possible reading of the text, it is not a likely one, given that Aristotle in this passage is pointing out that a virtuous person wishes goods to himself, and conceives of himself properly-he sees that he is "most of all" his intellect (9.4.1166a23). There is some motivation for taking the subject of all' ôn to be the subject of hairetai, and none for taking its subject to be theos. Aquinas, however, quite reasonably follows the translation in front of him, and so makes two mistakes. In EA 9.4 no. 1807, he infers that Aristotle's point is this:

One wills oneself to be in the sense that that which is oneself is preserved [conservatur]. But that which is most of all kept [conservatur] the same in its being is God, who of course does not will any good for himself that he does not now have, but now has in himself perfect good, and he always is what he is at any time, because he is immutable. Now we are most like God as regards intellect, which is incorruptible and immutable, and so the being of any person is considered most of all in connection with intellect, and so the virtuous man who lives entirely according to intellect and reason most of all wills that he himself be and live. He also wills that he be and live as regards what is lasting in him, but anyone who wills that he be and live primarily as regards the body, which is subject to change, does not truly will that he be and live.

This reading yields two mistakes: (1) it gives Aquinas some positive reason for thinking that Aristotle believed perfect human happiness could consist solely in the contemplative life; (2) it prevents Aquinas from seeing that in this passage Aristotle is ruling out the possibility that a human being could become a god (or a separate intellect).

The second place at which Aristotle commits himself to the view that no human being can become a god is at EN 8.7.1159a3-12. Aristotle asks if one wishes the greatest good to one's friend, namely, that the friend be a god. He answers negatively. To wish good to one's friend, one's friend must remain who he is (1159a10). One's (human) friend cannot be a god, so one cannot wish the greatest good for one's friend. 
Since Aquinas thinks that one's friend could become a god, 27 how can he interpret Aristotle's claim that one wishes good to one's (human) friend only insofar as he is human? First he points out that if one's friend becomes a god, then one's friend would no longer have friends, since gods have no friends (EN 8.7.1159a7-8; EA 8.7 no. 1636). But if one's friend changed and ceased to have friends, one would lose his friendship and so would lose a friend. But since one loves oneself most of all, one will not wish the greatest good for one's friend at the cost of the loss of a lesser good to oneself (EA 8.7 no. 1638 ).

This interpretation makes Aristotle sound uncharacteristically selfcentered, especially in view of his claim at $9.8(1169 \mathrm{a} 18-20)$ that a virtuous person would be willing to die for friends and country if need be. Aquinas is well aware of the ways in which Aristotle thinks a virtuous person will be self-sacrificing, ${ }^{28}$ but he points out in his comment on the passage that the sacrifice is still for the sake of a greater good for oneself (EA 9.9 no. 1878). This sort of self-sacrificing is theoretically consistent, therefore, with Aquinas's interpretation of EN 8.7, since both assume that the goods one wishes others are limited by what is in one's own self-interest. They are not in perfect harmony, however. If there are some circumstances in which you will give your life for a friend, why might you not wish your friend to become a god even if that would deprive you of friendship with the other? This difficulty by itself does not rule out Aquinas's interpretation of EN 8.7, since he can take it as a description of how friendships

27. The first hint we have that something has gone wrong in Aquinas is that while the greatest good according to Aristotle (both in the Greek and the Latin translation) is to be [a] god (1159a7), Aquinas says the greatest good is to be [a] god, or [a] king, or most virtuous. Perhaps Aquinas makes these additions on the grounds that the pagans ascribe some sort of immortality or divinity to great individuals. For a summary of how Aquinas deals with Aristotle's skeptical remarks in the EN about immortality, see Harry V. Jaffa, Thomism and Aristotelianism (Chicago: Chicago University Press, 1952), pp. 146-148.

28. It is interesting to notice that where Aristotle says that under certain circumstances a virtuous person would be willing to die for his friends and country (tês patridos), the Latin translation Aquinas uses (at least most of the time) replaces tês patridos with pati, "suffer," making the claim that "one will do and suffer many things for one's friends." In his comment, however, Aquinas is faithful to Aristotle, saying that "one would do many things for friends and country [patriae]." 
normally do operate. Normally one covets a valued friend and is sorrowed to some degree at the thought of losing the friend, even if that means the friend would be better off.

What we must notice about Aquinas's interpretation of EN 8.7 is that by assuming that being a god and being most virtuous are relevantly similar for his purposes, Aquinas gains further evidence that Aristotle took seriously the idea that a human being could become a separate intellect. Thus he fails again to learn that Aristotle did not take this seriously. So according to Aquinas's Aristotle, we are significantly far from being completely happy if we are leading an active life in accordance with the virtues of magnificence, magnanimity, generosity, and so on. If we become "gods" and lead a secluded contemplative life, however, we lead a life which is very nearly completely happy. ${ }^{29}$

Perhaps the most obvious objection to raise against this view is that while contemplation of the truth might count as complete happiness for a purely intellectual being, it cannot count as complete happiness for a rational animal with a compound nature, especially if happiness is the fulfillment of one's specifying capacities. Aquinas himself raises this objection (EA 10.11 nos. 2105-2106). He quotes Aristotle as claiming that "it would be absurd if one were to choose to live not in accordance with a life proper to oneself but in accord with a life [proper] to something else" (no. 2109). Indeed, it would be even stranger if one's happiness consisted in the fulfillment of a life not proper to oneself.

But these words are part of Aquinas's defense. Intellect is that which is most fundamental (principalissimum) in human beings (EA 10.11 no. $2110 ; 10.12$ no. $2116 ; 10.13$ nos. $2135-2136$ ), and so the life most appropriate for a human being is the life of intellectual activity (10.11 nos. 2105-2110). ${ }^{30}$ This answer will not work, how-

29. Aquinas does claim that Aristotle accepts the view that no recognizably human life can be truly happy at EA 1.9 no. 113 ; 1.10 no. 129 ; 10.11 nos. $2102-$ 2116.

30. Aquinas does not advocate the secluded, contemplative life except in peculiar circumstances (see ST 2-2.188.8), for he does not even think that in this life we can attain true contemplative happiness. Thinking we could was a mistake of Averroes's that Aquinas is eager to defeat; for Aquinas, true happiness can be attained only in the beatific vision after death. For Averroes's position, see Commentarium magnum in Aristotelis De anima libros 3.36 (edited by F. S. Crawford [Cambridge, Mass.: The 
ever, if the intellect that we are fundamentally is our practical intellect, the rational faculty that guides our active life. Aquinas notices that Aristotle sometimes seems to be suggesting that it is our speculative intellect which we are fundamentally (EN 10.7.1177a15, 1178a2; compare EA 10.10 nos. 2080-2086; 10.11 nos. 2107-2110). What Aquinas does not take to heart is that Aristotle shows, after all the praise he has heaped upon the speculative intellect, that it is still our practical intellect that we are fundamentally. ${ }^{31}$

Aquinas will be justified in not taking this passage to heart in this way if he can find some passage where Aristotle makes clear that someone who is a human being at some time may also legitimately be considered to be not only a compound but also an intellect capable of independent existence. In fact, he thinks he can find just such a passage.

It is clear that prudence and moral virtue are equally related to [circa] the composite [of body and soul]. The virtues of the composite, properly speaking, are human in so far as a human being [homo] is composed of soul and body. So life, [which is lived] . . . according to prudence and moral virtue, is human, and this is called the active life. Consequently happiness which consists in this life [i.e., in the active life] is human. But the speculative life and speculative happiness, which are proper to the intellect, are separate and divine.

Mediaeval Academy of America, 1953], pp. 479-502). For Aquinas's argument against Averroes, see Contra gentiles 3.41-45; and Pegis, "St. Thomas and the Nicomachean Ethics."

3I. EN 10.8.1178b5. See also EN 9.8.1168b25-1169b2, where Aristotle points out that the admirable self-lover, the one who loves what he is most fundamentally, loves his practical intellect. Kraut argues that in 10.7 Aristotle does accept that we are, fundamentally, our speculative intellect (see Kraut, Aristotle on the Human Good, pp. 4 n. $5,129,183,184,352$ n. 34). This interpretation is undercut by three things. (1) At $1178 \mathrm{a} 7$, Aristotle hedges his claims about the merits of the speculative life by adding the condition "if a human being is most of all his [speculative] intellect." If we are most of all that which is "controlling" in us, that which represents the interests of the whole soul, then he denies the antecedent of this conditional. (2) At $1177 \mathrm{~b} 26$ he points out that the speculative life is not a human life. In what follows, Aristotle argues that we should not let this stop us from pursuing speculation. Of course this does not entail that he thinks the purely speculative life is the best life for a human being. (3) In 10.8 Aristotle shows that he has not lost sight of the fact that we are human beings and hence are to be identified most of all with our practical intellects (see especially $1178 \mathrm{~b} 5$ ). 
For present purposes it is sufficient to say just this much, for a fuller explanation would be more than is directly relevant to the issue. This matter is treated in the third book of the On the Soul [3.4.430a22] where it is shown that intellect is separate. So it is clear that speculative happiness is better than, or preferable to [potior], active happiness by as much as something separate and divine is better than, or preferable to [potior], that which is composite and human. (EA 10.12 nos. 2115-2116)

What we must see first here is that whatever Aristotle may mean in the relevant passage of the On the Soul, in the passage of the EN that Aquinas is explicating here, Aristotle nowhere claims that intellect is separate from the compound of soul and body. What Aristotle does claim is that "the virtue of intellect is separate [from the compound]" ("hê de tou nou kechôrismenê," 1178a22; "Quae autem intellectus, separata"). Of course one way that the virtues of the intellect could be separate, i.e., capable of existence independent of the compound, would be if they resided in a part of us that was separate from the compound. Of course, that is not the only way in which they could be separate. They could be separate simply in virtue of the fact that some beings do possess them, but that those beings (gods), do not possess bodies as we do. This latter claim does not entail that our intellects are separate from the compound of soul and body unless one also accepts that we can become "gods." 32 The text does not rule out Aquinas's interpretation, and since he needs it to defend Aristotle against an important objection, it is reasonable for him to take it the way he does. Even so, all things considered, the interpretation seems incorrect.

Given his interpretation of the passage, Aquinas can claim that Aristotle does not find it absurd to say that our true happiness consists in living a life that is not proper to something composed of body and soul. It is not absurd because most fundamentally what we are is an intellect that is separate from the compound of body and soul. A life proper to the intellect can be a life proper to us even though it is not a life proper to something composed of body and soul.

\section{CONCLUSION}

On Aquinas's account, the happiness we can achieve in this life is neither complete nor self-sufficient. Our happiness can 
come closer to being complete and self-sufficient if we live the contemplative life. Thus Aquinas distinguishes three types of happiness:

H1: Happiness of the active life, the happiness of the life lived according to the moral virtues

H2: Earthly, superhuman happiness, the contemplative life of an embodied soul that requires some external goods

$\mathrm{H} 3$ : Superhuman happiness to the fullest extent, the beatitude involving one's speculative intellect and one's resurrected body 33

The most perfect happiness to be attained in this life, therefore, would be $\mathrm{H} 2$, a life that is as much like $\mathrm{H} 3$ as is possible in this life. ${ }^{34}$

The contemplative life is more self-sufficient than the active life, on the grounds that the contemplative life requires fewer external goods (EA 10.10 nos. 2093-2096; 10.12 nos. 2117-2120). The contemplative life requires only the bare necessities, such as food and drink (nos. 2093, 2117). The active life requires more. To be just, for example, one must have other people to whom to be just, and others with whom to cooperate in doing just acts (no. 2094). The contemplative life, therefore, is more self-sufficient if we take selfsufficiency in the exclusive sense.

The contemplative life is more complete than the active life on the grounds that contemplation of the truth is its own reward. It is not desired for the sake of anything else, while someone always acquires something extra from external actions (EA 10.10 no. 2097; 10.11 nos. 2101-2104). Virtuous action usually brings honor or favor (no. 2097). Aquinas is not saying that virtuous actions are done for the sake of these other goods, but only that part of their attractiveness for us is that they are the sorts of actions that yield these good results. More importantly, all of the moral virtues are directed to the common good which is desired because it affords the opportunity of contemplating the truth (no. 2101-2102). Hence the immediate goals of the

showing that intellect can exist independently from a compound of soul and body, unless one also accepts that we can become "gods" in the relevant way.

33. Compare ST 1-2.69.3. Actually there are two types of $\mathrm{H} 3$, one without the resurrected body and one with it (cf. ST 1-2.4.5 corp and ad 5).

34. See O. Brown, "Saint Thomas, the Philosophers, and Felicity," Laval théologique et philosophique 37 (1981): 69-82, especially p. 71 . 
active life are themselves desired for the sake of the contemplation of the truth, and so the active life is not complete, and so not happy (no. 2102).

Nothing Aquinas did in developing his interpretation is philosophically suspect. Aquinas has independent reasons for thinking that it is impossible for us to attain our ultimate end in this life. As a sympathetic interpreter of Aristotle, he will not attribute what he takes to be a false view to Aristotle if he can find some textual grounds for attributing to him what he takes to be the true view. In the interpretations we have just seen, as well as passages about the contemplative life in EN 10, Aquinas's interpretation is certainly motivated. In fact, in his interpretation of EN 9.4 (1166a20-22), we saw that he had the best translation of the text in front of him, but unfortunately the Latin translator made an important mistake. Aquinas does have to do quite a bit of work to make his interpretation cohere with everything Aristotle says, but we have not seen him make any illegitimate moves in defending his interpretation, and, given the state of the text, any good interpretation will encounter many textual difficulties. ${ }^{35}$

California State University, San Bernardino

35. For more on the question of whether Aquinas's commentary is philosophically suspect, see Joseph Owens, "Aquinas as Aristotelian Commentator," in St. Thomas Aquinas, 1274-1974: Commemorative Studies (Toronto: PIMS, 1974), pp. 213-238. We have also seen enough to argue against Gilson that if Aquinas's commentaries on Aristotle are merely expositions of Aristotle's doctrines, that is not incompatible with their also being expositions of his own philosophy. See Etienne Gilson, History of Christian Philosophy in the Middle Ages (New York: Random House, 1955), p. 367. I am deeply indebted to Normann Kretzmann and to Terence Irwin for helpful comments on earlier drafts of this paper. 